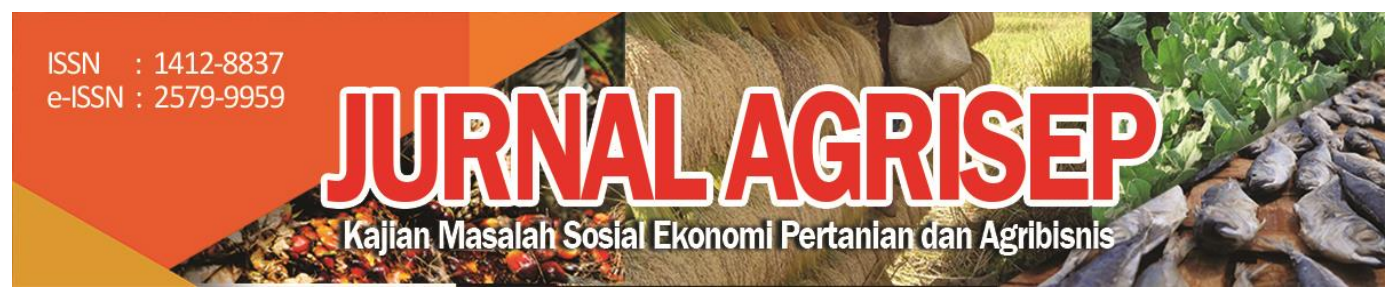

DOI: $10.31186 /$ jagrisep.19.2.389-406

\title{
ANALISIS MODEL KELEMBAGAAN AGRIBISNIS BUAH NAGA ORGANIK, DESA JAMBEWANGI, KABUPATEN BANYUWANGI
}

\author{
Analysis of Agribusiness Institutional Model of Organic Dragon Fruit, \\ Jambewangi, Banyuwangi
}

\author{
Riza Rahimi Bachtiar1) \\ 1)2)3) Program Studi Agribisnis, Politeknik Negeri Banyuwangi \\ Email: rizarahimi@poliwangi.ac.id
}

\begin{abstract}
The development of leading commodity agribusiness centers was an initial activity to develop economic area, especially in Banyuwangi. One area in Banyuwangi that had great potential in the development of the dragon fruit agribusiness center was Jambewangi. The implementation of this organic dragon fruit farming system had various advantages including: the price of dragon fruit could be sold higher, environmentally friendly, and healthy. However, there were several problems in Jambewangi, such as the marketing system of organic dragon fruit still not optimal because farmers could not directly sell the dragon fruit to consumers. Organic dragon fruit farmers must deposit their harvests to middlemen (collector traders), therefore the benefits were not optimal. Another problem was dragon fruit as a perishability, seasonal, requires a lot of space, and not uniform.

The various problems above caused the need for an institutional design model of organic dragon fruit agribusiness to increase farmer's incomes. This study was aimed to design and analyze the institutional model of organic dragon fruit agribusiness in Jambewangi, Banyuwangi. The sampling method used in this study was the Snowball Sampling method. The results showed that the organic red dragon fruit trading system in Jambewangi consisted of: a) Farmers - Village Collector Traders - Regency Collector Traders - Supermarkets - Consumers. b) Farmers - Regency Collector Traders Supermarkets - Consumers. c) Farmers - Village Collector Traders - Retailer Traders Consumers. d) Farmers - Retailers - Consumers. e) Farmers - Regency Collector Traders - Retailer Traders - Consumers. f) Farmers - Regency Collector Traders - Consumers. g) Farmers - Consumers. The most efficient trading system channel was Channel 7, which
\end{abstract}


is marketing organic dragon fruit from farmers and then channeled directly to consumers.

Keywords: agribusiness, dragon fruit, jambewangi, institutional model, organic.

\begin{abstract}
ABSTRAK
Pembangunan sentra agribisnis komoditas unggulan adalah kegiatan awal untuk memacu pembangunan ekonomi di suatu wilayah, khususnya di Kabupaten Banyuwangi. Salah satu daerah di Kabupaten Banyuwangi yang memiliki potensi besar di dalam pembangunan sentra agribisnis buah naga adalah desa Jambewangi. Penerapan sistem pertanian buah naga organik ini memiliki berbagai keuntungan antara lain : harga buah naga dapat dijual lebih tinggi, ramah lingkungan, dan menyehatkan. Namun, terdapat beberapa permasalahan di Desa Jambewangi yaitu sistem pemasaran buah naga organik masih belum maksimal dikarenakan petani tidak dapat langsung menjual buah naga tersebut kepada konsumen. Petani buah naga organik harus menyetorkan terlebih dahulu hasil panennya kepada tengkulak (pedagang pengumpul), sehingga keuntungan yang didapat tidak maksimal. Permasalahan lainnya adalah buah naga merupakan produk pertanian yang mudah rusak (perishability), musiman, membutuhkan ruang yang banyak, dan tidak seragam.

Berbagai permasalahan di atas menyebabkan dibutuhkannya suatu rancang bangun model kelembagaan agribisnis buah naga organik untuk meningkatkan pendapatan petani. Penelitian ini bertujuan untuk merancang dan menganalisis model kelembagaan agribisnis buah naga organik di Desa Jambewangi, Kabupaten Banyuwangi. Metode penentuan sampel yang digunakan dalam penelitian ini adalah metode Snowball Sampling. Hasil penelitian menunjukkan bahwa saluran tataniaga buah naga merah organik di Desa Jambewangi terdiri dari : a) Petani - Pedagang Pengumpul Desa - Pedagang Pengumpul Kabupaten - Supermarket - Konsumen. b) Petani - Pedagang Pengumpul Kabupaten - Supermarket - Konsumen. c) Petani Pedagang Pengumpul Desa - Pedagang Pengecer - Konsumen. d) Petani - Pedagang Pengecer - Konsumen. e) Petani - Pedagang Pengumpul Kabupaten - Pedagang Pengecer - Konsumen. f) Petani - Pedagang Pengumpul Kabupaten - Konsumen. g) Petani - Konsumen. Saluran tataniaga yang paling efisien adalah Saluran 7 yaitu pemasaran buah naga organik dari petani kemudian disalurkan secara langsung ke konsumen.
\end{abstract}

Kata kunci: agribisnis, buah naga, jambewangi, model kelembagaan, organik.

\title{
PENDAHULUAN
}

Buah naga merupakan salah satu komoditas unggulan di Kabupaten Banyuwangi. Hal ini dikarenakan berbagai manfaat yang dapat diperoleh dari buah naga antara lain : menurunkan kadar kolesterol, penyeimbang kadar gula darah, mencegah kanker usus, menguatkan fungsi ginjal dan tulang, menguatkan daya kerja otak, meningkatkan ketajaman mata serta sebagai bahan 
kosmetik (Suryono, 2006). Buah naga merupakan komoditas unggulan khususnya di Kabupaten Banyuwangi. Data total produksi komoditas unggulan buah-buahan di Kabupaten Banyuwangi dapat dilihat pada Tabel 1.

Tabel 1. Produksi Buah Naga di Kabupaten Banyuwangi

\begin{tabular}{rlrrrrrrr}
\hline \multirow{2}{*}{ No } & \multirow{2}{*}{ Komoditas } & \multicolumn{8}{c}{ Produksi (Kw) } \\
\cline { 3 - 9 } & & $\mathbf{2 0 1 3}$ & $\mathbf{2 0 1 4}$ & $\mathbf{2 0 1 5}$ & $\mathbf{2 0 1 6}$ & $\mathbf{2 0 1 7}$ & $\mathbf{2 0 1 8}$ & \multicolumn{1}{c}{ Total } \\
\hline $\mathbf{1}$ & Buah Naga & $16.630,60$ & 28.820 & 30.454 & 39.990 & $42.349,41$ & $44.140,74$ & 202.385 \\
\hline $\mathbf{2}$ & Mangga & $20.818,90$ & $22.815,30$ & 22.247 & 23.742 & $24.537,36$ & $25.035,17$ & 139.196 \\
\hline $\mathbf{3}$ & Rambutan & $13.627,38$ & $14.653,13$ & 10.779 & 11.256 & 19.633 .08 & $16.346,17$ & 66.662 \\
\hline $\mathbf{4}$ & Durian & $9.085,65$ & $11.108,22$ & 11.432 & 11.559 & $11.582,12$ & $11.909,67$ & 66.677 \\
\hline $\mathbf{5}$ & Melon & 17.430 & 8.479 & 9.517 & 9.824 & $9.153,10$ & $9.347,13$ & 63.750 \\
\hline
\end{tabular}

Sumber : Dinas Pertanian Kabupaten Banyuwangi, 2019

Tabel 1. menunjukkan bahwa total produksi buah naga sebesar 202.385 kuintal. Buah naga memiliki tingkat produksi yang paling tinggi dibandingkan dengan komoditas lainnya. Potensi komoditas unggulan daerah ini dapat dikembangkan dengan melakukan pembangunan sentra agribisnis. Pembangunan sentra agribisnis komoditas unggulan adalah kegiatan awal untuk memacu pembangunan ekonomi di suatu wilayah, khususnya di Kabupaten Banyuwangi. Salah satu daerah di Kabupaten Banyuwangi yang memiliki potensi besar di dalam pembangunan sentra agribisnis buah naga adalah desa Jambewangi. Terdapat beberapa petani di Desa Jambewangi yang telah menerapkan sistem pertanian buah naga organik. Penerapan sistem pertanian buah naga organik ini memiliki berbagai keuntungan antara lain : harga buah naga dapat dijual lebih tinggi, ramah lingkungan, dan menyehatkan. Namun, terdapat beberapa permasalahan di Desa Jambewangi yaitu sistem pemasaran buah naga organik masih belum maksimal dikarenakan petani tidak dapat langsung menjual buah naga tersebut kepada konsumen. Petani buah naga organik harus menyetorkan terlebih dahulu hasil panennya kepada tengkulak (pedagang pengumpul), sehingga keuntungan yang didapat tidak maksimal. Permasalahan lainnya adalah buah naga merupakan produk pertanian yang mudah rusak (perishability), musiman, membutuhkan ruang yang banyak, dan tidak seragam. Sifat mudah rusak ini menyebabkan komoditas buah naga organik membutuhkan sistem pemasaran yang cepat sampai ke tangan konsumen (Anindita, 2017). Sistem tataniaga yang baik dibutuhkan untuk dapat menyelesaikan permasalahan tersebut, terdapat beberapa penelitian tataniaga yang telah dilakukan antara lain dapat dilihat pada Tabel 2. 
Tabel 2. Penelitian Terdahulu mengenai Model Kelembagaan Tataniaga

\begin{tabular}{|c|c|c|c|}
\hline No & Peneliti dan Judul & Tujuan Penelitian & Hasil Penelitian \\
\hline 1. & $\begin{array}{l}\text { Amnimarlianda, et } \\
\text { al (2018) } \\
\text { melakukan } \\
\text { penelitian } \\
\text { berjudul Analisis } \\
\text { Pemasaran dan } \\
\text { Pendapatan } \\
\text { Usahatani } \\
\text { Semangka } \\
\text { Kelompok Tani } \\
\text { Ridho Lestari di } \\
\text { Desa Tembokrejo } \\
\text { Kecamatan } \\
\text { Muncar } \\
\text { Kabupaten } \\
\text { Banyuwangi. }\end{array}$ & $\begin{array}{l}\text { Tujuan dari penelitian ini } \\
\text { adalah untuk mengetahui } \\
\text { saluran pemasaran, marjin } \\
\text { dan efisiensi pemasaran, } \\
\text { serta pendapatan dan } \\
\text { usahatani semangka yang } \\
\text { terdapat pada kelompok } \\
\text { tani Ridho Lestari Desa } \\
\text { Tembokrejo Kecamatan } \\
\text { Muncar Kabupaten } \\
\text { Banyuwangi. }\end{array}$ & $\begin{array}{l}\text { Ada } 4 \text { pola saluran pemasaran } \\
\text { semangka yang melibatkan } 7 \\
\text { lembaga pemasaran meliputi petani, } \\
\text { tengkulak, pedagang besar, } \\
\text { pedagang pengecer, konsumen, } \\
\text { eksportir dan importir. Pola saluran } \\
\text { pemasaran semangka meliputi : } 1 . \\
\text { Petani - pedagang - pedagang } \\
\text { pengecer - konsumen; 2. Petani - } \\
\text { tengkulak - pedagang - pedagang } \\
\text { pengecer - konsumen; 3. Petani - } \\
\text { tengkulak - pedagang pengecer - } \\
\text { konsumen; } 4 \text { Petani - eksportir - } \\
\text { importir. Pemasaran semangka } \\
\text { ekspor memiliki nilai marjin } \\
\text { tertinggi dan tidak efisien } \\
\text { sedangkan saluran pemasaran } \\
\text { semangka non ekspor adalah } \\
\text { efisien. }\end{array}$ \\
\hline 2. & $\begin{array}{l}\text { Side, et al (2018) } \\
\text { melakukan } \\
\text { penelitian } \\
\text { berjudul Analisis } \\
\text { Sistem Pemasaran } \\
\text { Komoditi Bawang } \\
\text { Merah dengan } \\
\text { Pendekatan SCP di } \\
\text { Kelurahan Baruga } \\
\text { Dhua, Kecamatan } \\
\text { Banggae Timur, } \\
\text { Kabupaten } \\
\text { Majene, Provinsi } \\
\text { Sulawesi Barat. }\end{array}$ & $\begin{array}{l}\text { Tujuan dari penelitian ini } \\
\text { adalah untuk menganalisis } \\
\text { sistem pemasaran } \\
\text { komoditas bawang merah } \\
\text { dengan pendekatan SCP } \\
\text { (struktur pasar, perilaku } \\
\text { pasar dan kinerja pasar) di } \\
\text { Kelurahan Baruga Dhua, } \\
\text { Kecamatan Banggae } \\
\text { Timur, Kabupaten Majene, } \\
\text { Provinsi Sulawesi Barat. }\end{array}$ & $\begin{array}{l}\text { Ada } 4 \text { pola saluran dengan pola } \\
\text { meliputi : petani - UMKM Bina } \\
\text { Sejahtera - konsumen bawang } \\
\text { merah goreng; petani - pedagang } \\
\text { pengumpul - pedagang pengecer } \\
\text { lokal - konsumen; petani - } \\
\text { pedagang pengumpul - pedagang } \\
\text { pengecer luar daerah; petani - } \\
\text { pedagang pengumpul - pedagang } \\
\text { besar luar daerah. Struktur pasar } \\
\text { secara keseluruhan menunjukkan } \\
\text { kondisi pasar persaingan tidak } \\
\text { sempurna oligopsoni, kondisi } \\
\text { perilaku pasar menunjukkan bahwa } \\
\text { tidak adanya lembaga formal yang } \\
\text { mengatur harga komoditi bawang } \\
\text { merah akan tetapi perilaku berjalan } \\
\text { sebagaimana mestinya. Kinerja } \\
\text { pasar menunjukkan nilai efisiensi } \\
\text { tertinggi pada pola saluran } \\
\text { pemasaran I. }\end{array}$ \\
\hline 3. & $\begin{array}{l}\text { Ali, et al (2017) } \\
\text { melakukan } \\
\text { penelitian } \\
\text { berjudul Analisis } \\
\text { Efisiensi } \\
\text { Pemasaran Kubis } \\
\text { di Kecamatan } \\
\text { Gisting Kabupaten } \\
\text { Tanggamus. }\end{array}$ & $\begin{array}{l}\text { Tujuan dari penelitian ini } \\
\text { adalah untuk menganalisis } \\
\text { sistem pemasaran kubis di } \\
\text { Kecamatan Gisting } \\
\text { Kabupaten Tanggamus } \\
\text { dilihat dari struktur pasar, } \\
\text { perilaku pasar dan kinerja } \\
\text { pasar. }\end{array}$ & $\begin{array}{l}\text { Hasil penelitian ini menunjukkan } \\
\text { bahwa terdapat } 12 \text { pola saluran } \\
\text { pemasaran kubis yang terbentuk. } \\
\text { Struktur pasar dalam sistem } \\
\text { pemasaran kubis cenderung } \\
\text { menghadapi pasar persaingan tidak } \\
\text { sempurna oligopsonistik di tingkat } \\
\text { petani, tetapi oligopolistik di tingkat } \\
\text { konsumen. Penentuan dan }\end{array}$ \\
\hline
\end{tabular}




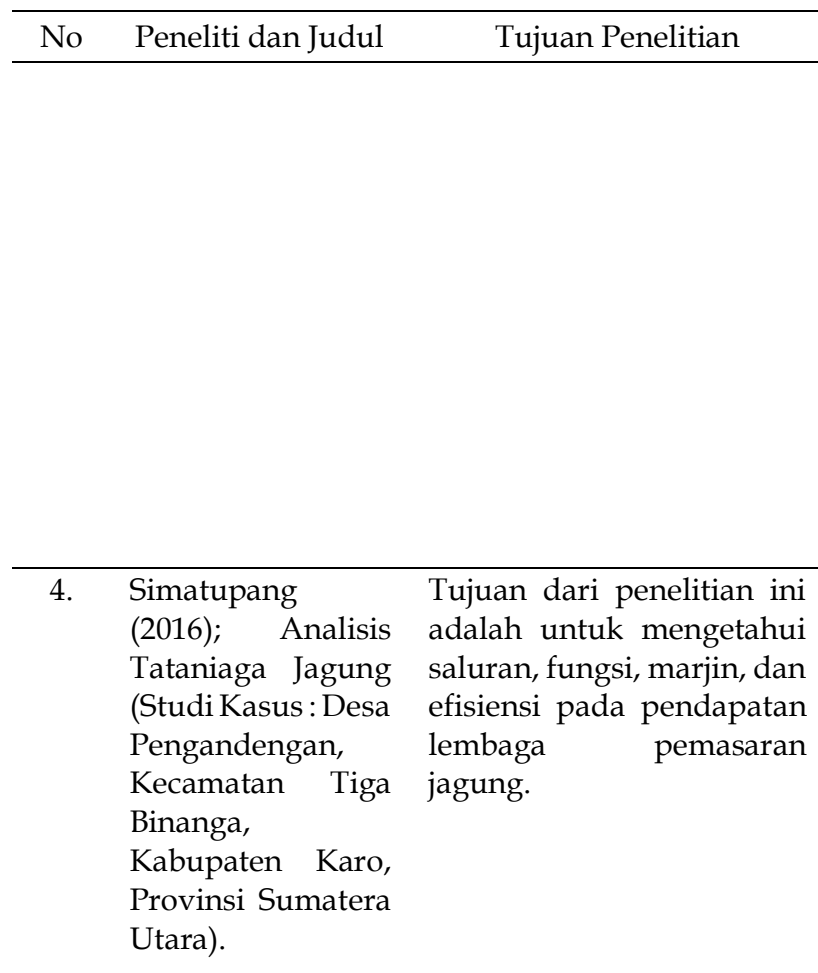

pembentukan harga yang terjadi cukup sederhana akan tetapi masih merugikan petani karena hanya sebagai price taker dan metode pembayaran cenderung sistem tunda bayar. Kinerja pasar menunjukkan farmer's share masih rendah, marjin pemasaran masih tinggi dan rasio keuntungan terhadap biaya belum merata. Laju perubahan harga di tingkat konsumen lebih besar dibandingkan dengan di tingkat petani.

Hasil penelitian menunjukkan bahwa terdapat satu saluran tataniaga jagung di daerah penelitian yaitu Petani - Pengumpul - Pedagang Besar - Pengecer Konsumen. Nilai perhitungan efisiensi tataniaga (Ep) pada saluran tersebut sebesar 21,57\% yang berarti belum efisien. Informasi harga pasar yang didapatkan oleh petani produsen tidak lebih cepat dibandingan dengan pedagang sehingga posisi tawar petani menjadi lemah. Hal ini menyebabkan keuntungan yang didapat petani lebih kecil dibandingkan dengan yang didapat pedagang.

5. Hidayat, et al Tujuan dari penelitian ini (2016); Analisis Tataniaga Jeruk Siam Banjar (Citrus reticulata) di Desa Karang Buah Kecamatan Belawang Kabupaten Barito Kuala. adalah untuk mengetahui saluran tataniaga, marjin tataniaga, farmer's share, efisiensi tataniaga dan permasalahan yang terdapat pada sistem tataniaga jeruk siam di Desa Karang Buah Kecamatan Belawang Kabupaten Barito Kuala.
Penelitian ini menunjukkan bahwa pada Desa Karang buah terdapat lima saluran tataniaga yang meliputi : 1 . Produsen - konsumen; 2. Produsen - pedagang pengecer konsumen; 3. Produsen - pedagang pengumpul - pedagang besar pedagang pengecer luar wilayah konsumen; 4. Produsen - pedagang pengumpul - pedagang pengecer konsumen; 5. Produsen - pedagang pengumpul - pedagang pengumpul luar wilayah - pedagang pengecer konsumen. Saluran tataniaga yang paling efisien adalah saluran I yang hanya melibatkan Petani Konsumen (farmer's share 100\%). Marjin tataniaga terbesar pada penelitian ini senilai Rp. 6.000/kg. 


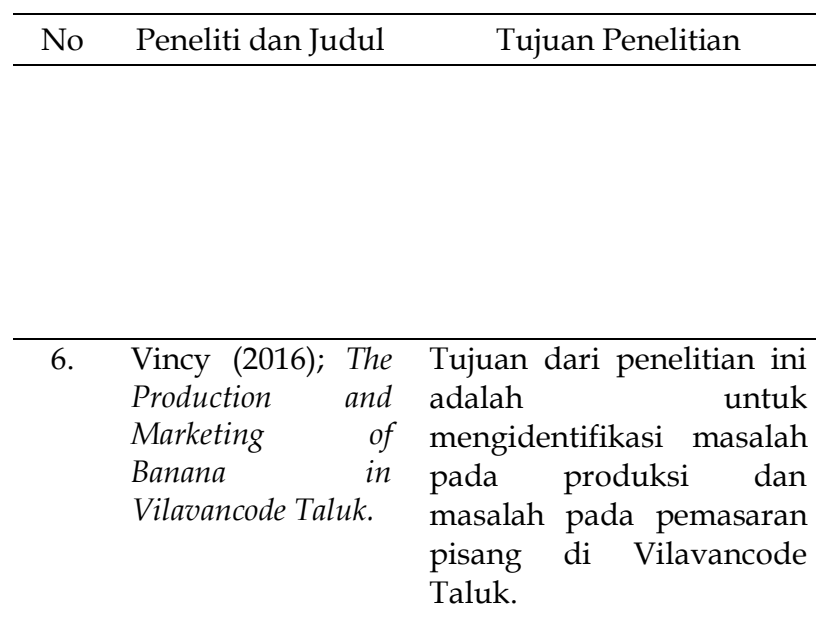

Permasalahan yang ada dalam

tataniaga jeruk siam yaitu pada saat panen raya petani kesulitan mencari pembeli, kerusakan jeruk saat penimbangan dan penurunan kesegaran jeruk karena pengiriman terlalu jauh.

Hasil penelitian ini menunjukkan bahwa permasalahan yang ada pada pemasaran pisang meliputi petani produsen memiliki tingkat pendidikan rendah $(42 \%$ tidak bersekolah) sehingga pengetahuan terhadap informasi pasar sangat rendah. Petani kesulitan dalam permodal dan diperparah dengan tidak adanya subsidi dari pemerintah untuk faktor input produksi.

$\begin{array}{lllr}\text { 7. Surahman } & \text { dan } & \text { Tujuan dari penelitian ini } \\ \text { Kusnadi } & (2016) ; & \text { adalah } & \text { untuk } \\ \text { Sistem Pemasaran } & \text { mengidentifikasi ristem } \\ \text { Nenas } r \text { Bogor } & \text { pemasaran dan efisiensi } \\ \text { (Ananas comosus) } & \text { sistem pemasaran nenas } \\ \text { di Kabupaten } & \text { bogor yang terbentuk. } \\ \text { Bogor. } & \end{array}$

Petani nenas melakukan fungsi tataniaga secara individu sehingga posisi tawar petani sangat lemah. Terdapat 3 lembaga tataniaga dengan 8 saluran tataniaga yang keseluruhan pola tataniaga belum efisien. Saluran yang dominan digunakan petani adalah saluran $\mathrm{V}$ dengan pola Petani - Pedagang Pengumpul Desa - Pengecer Konsumen yang memiliki nilai farmer's share $28,57 \%$ dan marjin Rp. $3.928,57$ (2,5 kali lipat dari harga yang ditawarkan di tingkat petani).

8. Aji, et al (2015); Tujuan dari penelitian ini Analisis Tataniaga adalah untuk mengetahui Kubis (Brassica saluran oldesa eraceae) tataniaga,keuntungan (Studi Kasus di petani dari beberapa Desa Deles saluran tataniaga, dan Kecamatan efisiensi saluran tataniaga.

Bawang

Kabupaten

Batang).
Ada 3 pola pemasaran dengan 4 lembaga tataniaga yang terlibat dalam tataniaga jagung. Pola saluran tataniag meliputi saluran tingkat nol (Petani - Konsumen); saluran tingkat satu (Petani Pengecer - Konsumen); saluran tingkat (Petani - Pengepul Pengecer - Konsumen). Keuntungan terbesar didapat petani apabila menggunakan saluran tingkat nol sehingga saluran tingkat nol banyak dipilih petani dalam menjual produknya.

Sumber: Data Sekunder, 2019 
Berbagai penelitan terdahulu mengenai modal kelembagaan dan sistem tataniaga menunjukkan bahwa dibutuhkan solusi untuk mengatasi berbagai permasalahan tataniaga di Desa Jambewangi. Permasalahan lain di Desa Jambewangi adalah saluran tataniaga buah naga organik yang belum diketahui oleh pelaku tataniaga buah naga organik di desa tersebut. Hal ini menyebabkan pelaku tataniaga buah naga organik, tidak mengetahui saluran mana yang paling efisien, sehingga keuntungan yang didapat oleh pelaku tataniaga belum maksimal.

Berbagai permasalahan di atas menyebabkan dibutuhkannya suatu rancang bangun model kelembagaan agribisnis buah naga organik untuk meningkatkan pendapatan petani. Kelembagaan agribisnis yang terpadu (terintegrasi) dapat menjembatani berbagai kesenjangan yang terjadi di tingkat produsen hingga konsumen. Penelitian ini bertujuan untuk merancang dan menganlisis model kelembagaan buah naga organik di Desa Jambewangi, Kabupaten Banyuwangi.

\section{METODE PENELITIAN}

Penelitian dilakukan di Desa Jambewangi Kecamatan Sempu sebagai produsen buah naga merah organik. Penentuan lokasi penelitian dilakukan secara sengaja (purposive). Lokasi yang dipilih sebagai objek penelitian adalah Kelompok Tani Pucang Sari karena merupakan satu-satunya kelompok tani buah naga merah organik di Kabupaten Banyuwangi yang telah memiliki sertifikasi organik dengan nomor Reg. 293-LSO-005-IDN-12-18. Lokasi penelitian dilakukan di Desa Jambewangi dikarenakan desa tersebut merupakan satu-satunya penghasil buah naga organik di Kabupaten Banyuwangi. Waktu penelitian dilaksanakan pada bulan Mei-November 2019. Penelitian ini menggunakan pendekatan kuantitatif dan kualitatif (mix method). Metode penelitiaan campuran (mix method) merupakan kategori ketiga dalam pendekatan penelitian, dalam penelitian sosial ekonomi pertanian memiliki ciri yang substantif mengharuskan peneliti menggunakan dua data sekaligus (kualitatif dan kuantitatif) (Dwiastuti, 2017). Herdiansyah (2012) menjelaskan bahwa penelitian kualitatif merupakan suatu penelitian ilmiah yang bertujuan untuk memahami suatu fenomena dalam konteks sosial secara alamiah dengan mengedepankan proses interaksi yang mendalam antara peneliti dan fenomena yang diteliti. Data yang dihasilkan dalam pendekatan kualitatif lebih berkenaan dengan interpretasi terhadap data yang ditemukan di lapangan (Sugiyono, 2017). Penelitian kualitatif dalam penelitian ini digunakan untuk mengetahui saluran tataniaga. Penelitian kuantitatif yaitu penelitian menggunakan instrumen dan diolah secara statistik (Mulyadi, 2011). 


\section{HASIL DAN PEMBAHASAN}

\section{Analisis Model Kelembagaan Agribisnis Buah Naga Organik}

Sistem tataniaga buah naga merah organik di Desa Jambewangi dimulai dari petani sampai pada konsumen dengan melibatkan beberapa lembaga tataniaga. Lembaga-lembaga tataniaga tersebut membantu menyalurkan buah naga merah organik sebagai hasil panen dari petani sampai pada konsumen akhir. Lembaga tataniaga yang terlibat dalam sistem tataniaga tersebut meliputi pedagang pengumpul desa, pedagang pengumpul kecamatan, pedagang pengumpul kabupaten, pedagang pengecer dan supermarket. Keseluruhan lembaga tataniaga dalam kelembagaan tataniaga tersebut memiliki peranan masing-masing. Peranan masing-masing lembaga tataniaga adalah sebagai berikut:

1. Petani berperan sebagai produsen dalam kegiatan produksi buah naga merah organik.

2. Pedagang pengumpul desa berperan sebagai pengumpul buah naga merah organik dari anggota kelompok tani buah naga merah organik. Pedagang pengumpul desa juga merupakan petani dan ketua kelompok tani yang sudah memiliki sertifikasi buah naga merah organik bertanggung jawab memberikan pelatihan, pendampingan dan motivasi kepada petani untuk melakukan teknik budidaya secara organik.

3. Pedagang pengumpul kecamatan berperan sebagai pengumpul buah naga merah organik dari petani maupun pedagang pengumpul lainnya yang berlokasi di luar Kecamatan Sempu.

4. Pedagang pengumpul kabupaten berperan sebagai pengumpul buah naga merah organik dari petani maupun pedagang pengumpul berlokasi di luar Kabupaten Banyuwangi.Pedagang pengecer berperan sebagai penyalur buah naga merah organik kepada konsumen. Konsumen yang dimaksud adalah konsumen akhir yang mengonsumsi buah naga merah organik.

5. Supermarket berperan sebagai penyalur buah naga merah organik kepada konsumen. Konsumen adalah konsumen akhir yang mengonsumsi buah naga merah organik.

Berdasarkan penelusuran dan wawancara yang telah dilakukan, petani memilih lembaga tataniaga berdasarkan kualitas dari buah naga merah organik yang dihasilkan. Beberapa lembaga tataniaga meinginkan grade tertentu pada saat pembelian buah naga merah organik. Grade buah naga yang terdapat pada penelitian ini terdiri dari buah naga merah organik lokal standar (grade A dan grade $B$ ) dan buah naga merah organik borongan. Kriteria grade buah naga merah organik dapat dilihat pada Tabel 1.2. 
Tabel 3 Kriteria Grade Buah Naga Merah Organik

\begin{tabular}{cc}
\hline Grade Buah Naga Merah Organik & Ukuran (Gram) \\
\hline A & $\geq 370$ \\
B & $270 \leq B<370$ \\
Sisa sortir & $\leq 270$ \\
\hline
\end{tabular}

Sumber: Data Primer Diolah, 2019

Tabel 3 menunjukkan grade buah naga merah organik yang terdapat pada sistem tataniaga buah naga merah organik Desa Jambewangi. Ukuran dari buah naga merah organik memiliki pengaruh cukup besar pada harga beli yang akan diterima petani dan harga jual yang akan dibayar konsumen. Perbedaan harga cukup signifikan ini disebabkan oleh segmentasi pasar yang dituju pada masingmasing grade dari buah naga merah organik. Lembaga tataniaga supermarket menginginkan produk buah naga merah organik grade A sehingga petani yang menginginkan tujuan tataniaga ke supermarket harus dapat memenuhi standar tersebut. Saluran tataniaga yang terdapat pada buah naga merah organik terdiri dari barang lokal grade standar dan barang borongan. Saluran tataniaga buah naga merah organik dapat dilihat pada Gambar 1

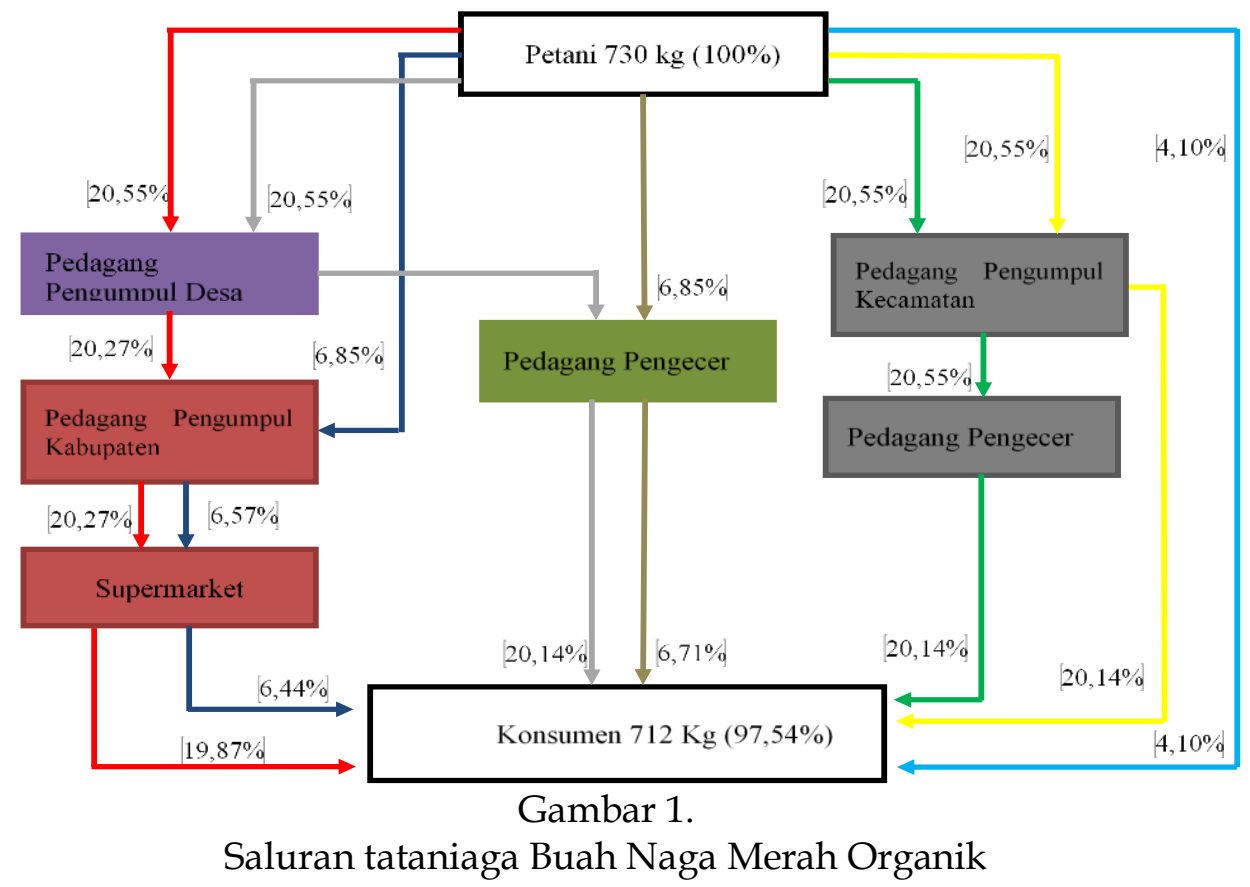

Keterangan:

_ : Saluran tataniaga 1

_ $\quad$ : Saluran tataniaga 2

: Barang lokal standar
: Barang grade A
: Barang grade B

AGRISEP Vol. 19 No. 2 September 2020 Hal: 389 - 406| 397 


\section{- : Saluran tataniaga 4 \\ - Saluran tataniaga 5 \\ :Saluran tataniaga 6 \\ - : Saluran tataniaga 7}

: Barang sisa sortir

Gambar 1. menunjukkan saluran tataniaga buah naga merah organik mulai dari petani sampai pada konsumen. Hasil panen buah naga merah organik dari petani responden sebanyak $730 \mathrm{~kg}$ dijual ke pedagang pengumpul desa sebanyak $41,10 \%$, pedagang pengumpul kabupaten sebanyak $6,85 \%$, pedagang pengumpul kecamatan sebanyak $41,10 \%$, pedagang pengecer sebanyak $6,85 \%$ dan konsumen sebanyak 4,10\%. Buah naga merah organik di Desa Jambewangi dijual berdasarkan grade produk. Produk dengan grade A dan grade B oleh petani dijual ke pedagang pengumpul desa sedangkan produk yang tidak memenuhi standar dijual secara borongan ke pedagang pengumpul kecamatan maupun dijual secara langsung ke konsumen. Gambar 4.1 juga menunjukkan bahwa terdapat 7 saluran tataniaga buah naga merah organik di Desa Jambewangi. Analisis dari masing-masing saluran tataniaga tersebut adalah sebagai berikut:

\section{Analisis Saluran tataniaga 1}

Saluran tataniaga 1 berasal dari 2 orang petani responden buah naga merah organik Desa Jambewangi dapat dilihat pada Gambar.2.

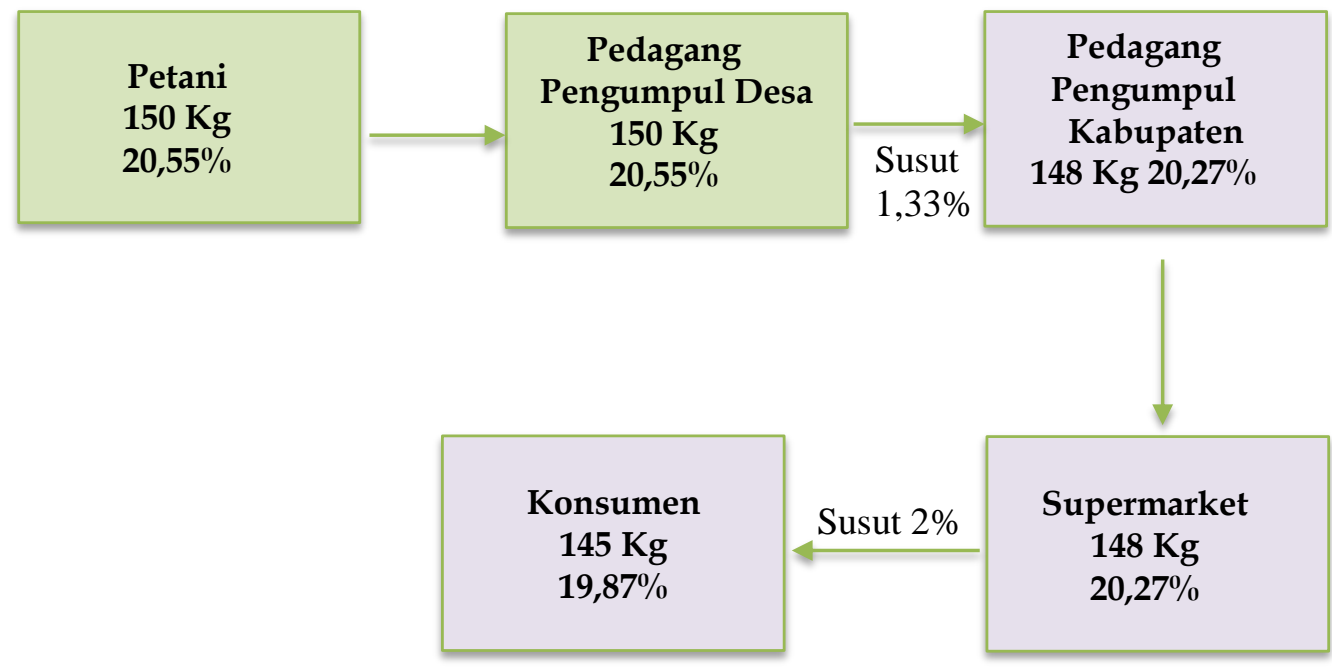

Gambar 2.

Saluran tataniaga 1

Keterangan: = buah naga merah organik grade $\mathrm{A}$

$=$ buah naga merah organik grade lokal standar

398 | Riza Rahimi Bachtiar, Abdul Holik, Danang SWPJ Widako; Analisis... 
Gambar 2 menunjukkan saluran tataniaga 1, petani responden buah naga merah organik Desa Jambewangi yang menggunakan saluran tataniaga 1 sebanyak 2 orang petani dengan kuantitas sebesar $150 \mathrm{~kg}$. Buah naga merah organik dari petani dijual ke pedagang pengumpul desa, kemudian oleh pedagang pengumpul desa dilakukan proses grading sesuai dengan permintaan pedagang pengumpul kabupaten yang menginginkan produk dengan grade A, proses pengemasan serta proses pelabelan organik. Hasil dari buah naga merah organik yang lolos standar grade A sebesar $150 \mathrm{~kg}$ memiliki harga di tingkat petani sebesar Rp. 21.000/ kg. Selanjutnya oleh pedagang pengumpul desa produk buah naga merah organik disalurkan ke pedagang pengumpul kabupaten dengan harga Rp.30.000/ kg. Pada sistem tataniaga di tingkat pedagang pengumpul kabupaten terdapat penyusutan kuantitas buah naga merah organik sebesar $2 \mathrm{~kg}$, kerugian dari adanya risiko penyusutan ini ditanggung oleh pedagang pengumpul desa dengan cara penambahan kuantitas saat pengiriman periode depan. Pedagang pengumpul kabupaten menyalurkan produk buah naga merah organik ke supermarket dengan harga jual Rp. 36.000/ $\mathrm{kg}$, kemudian supermarket menjual produk ke konsumen dengan harga Rp. $40.000 / \mathrm{kg}$, di tingkat supermarket terdapat penyusutan kuantitas buah sebesar $2 \%$ karena fungsi pengangkutan dan fungsi penyimpanan. Konsumen yang terdapat pada saluran tataniaga 1 sejumlah 73 orang dengan asumsi rata-rata pembelian $2 \mathrm{~kg}$.

\section{Analisis Saluran tataniaga 2}

Saluran tataniaga 2 berasal dari satu orang petani responden buah naga merah organik Desa Jambewangi dapat dilihat pada Gambar 3.

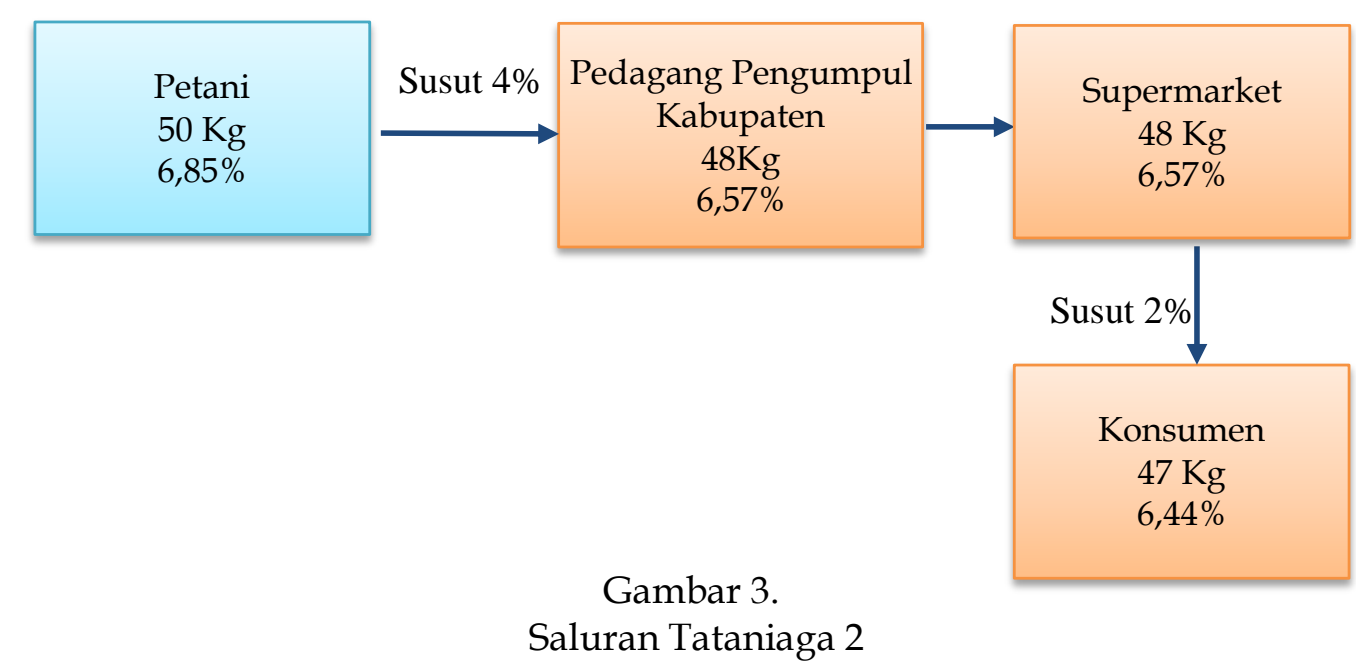

Keterangan: = buah naga merah organik grade $\mathrm{A}$

= buah naga merah organik grade lokal standar 
Gambar 3 menunjukkan saluran tataniaga 2, petani responden buah naga merah organik Desa Jambewangi yang menggunakan saluran tataniaga 2 sebanyak satu orang petani dengan kuantitas sebesar $50 \mathrm{~kg}$. Buah naga merah organik grade A dari petani yang juga merupakan pedagang pengumpul desa disalurkan bersamaan dengan produk dari saluran tataniaga 1 ke pedagang pengumpul kabupaten setelah melalui proses pengemasan dan pelabelan organik. Harga jual di tingkat petani sebesar Rp. 30.0000, pedagang pengumpul kabupaten menyalurkan produk buah naga merah organik ke supermarket dengan harga jual Rp. $36.000 / \mathrm{kg}$. Pada tingkat pedagang pengumpul kabupaten terdapat penyusutan buah naga merah organik sebesar $4 \%$ karena adanya fungsi pengangkutan. Risiko penyusutan ini menjadi biaya yang dibebankan pada petani. Supermarket menjual produk ke konsumen dengan harga Rp. 40.000/ $\mathrm{kg}$, di tingkat supermarket terdapat penyusutan buah naga merah organik sebesar $2 \%$ akibat adanya fungsi pengangkutan dan fungsi penyimpanan. Konsumen yang terdapat pada saluran tataniaga 1 sejumlah 25 orang dengan asumsi rata-rata pembelian $2 \mathrm{~kg}$.

\section{Analisis Saluran tataniaga 3}

Saluran tataniaga 3 berasal dari dua orang petani responden buah naga merah organik Desa Jambewangi dapat dilihat pada Gambar 4.

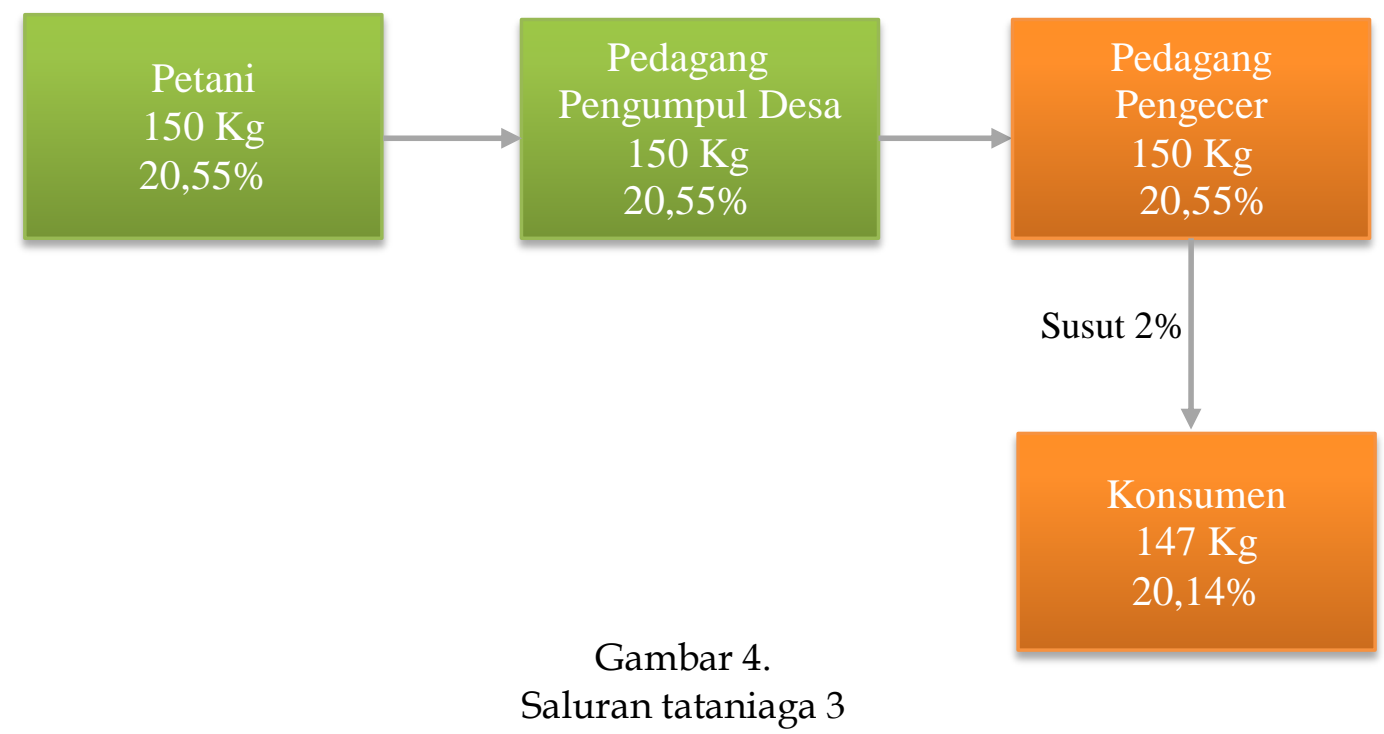

Keterangan: = buah naga merah organik grade $\mathrm{B}$

= buah naga merah organik grade lokal standar

Gambar 4. menunjukkan saluran tataniaga 3, petani responden buah naga merah organik Desa Jambewangi yang menggunakan saluran tataniaga 3 sebanyak 2 orang petani dengan kuantitas sebesar $150 \mathrm{~kg}$. Buah naga merah

400 | Riza Rahimi Bachtiar, Abdul Holik, Danang SWPJ Widako; Analisis... 
organik dari petani dijual ke pedagang pengumpul desa, kemudian oleh pedagang pengumpul desa dilakukan proses sortasi dan grading sesuai dengan permintaan pedagang pengecer yang menginginkan produk dengan grade B, proses pengemasan serta proses pelabelan organik. Hasil dari buah naga merah organik yang lolos standar grade B sebesar $150 \mathrm{~kg}$ memiliki harga di tingkat petani sebesar Rp. 12.000/ kg. Selanjutnya oleh pedagang pengumpul desa produk buah naga merah organik disalurkan ke pedagang pengecer dengan harga Rp.14.500/ kg. Pedagang pengecer menyalurkan produk buah naga merah organik ke konsumen dengan harga jual Rp. 20.000/ kg. Pada tingkat pedagang pengecer terdapat penyusutan kuantitas buah naga merah organik sebesar $2 \%$ akibat adanya fungsi penyimpanan. Konsumen yang terdapat pada saluran tataniaga 3 sejumlah 75 orang dengan asumsi rata-rata pembelian $2 \mathrm{~kg}$.

\section{Analisis Saluran tataniaga 4}

Saluran tataniaga 4 berasal dari satu orang petani responden buah naga merah organik Desa Jambewangi dapat dilihat pada Gambar 5.

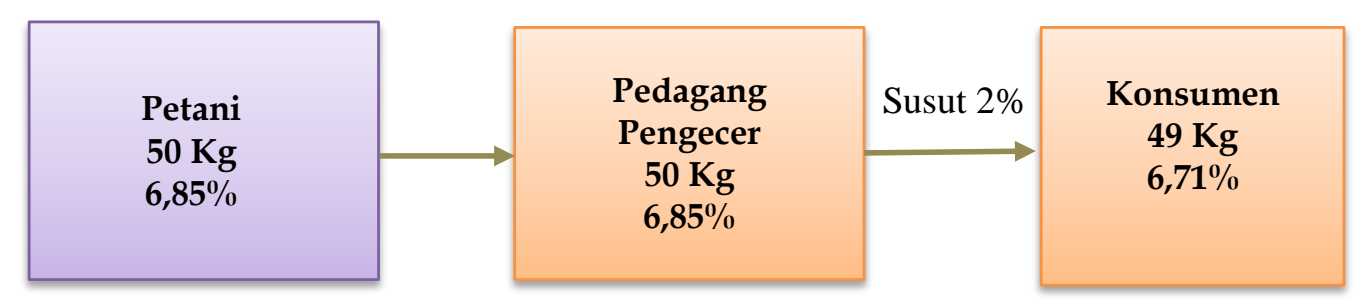

Gambar 5.

Saluran tataniaga 4

Keterangan: = buah naga merah organik grade $\mathrm{A}$ = buah naga merah organik grade lokal standar

Gambar 5 menunjukkan saluran tataniaga 4, petani responden buah naga merah organik Desa Jambewangi yang menggunakan saluran tataniaga 4 sebanyak satu orang petani dengan kuantitas sebesar $50 \mathrm{~kg}$. Buah naga merah organik grade B dari petani yang juga merupakan pedagang pengumpul desa disalurkan bersamaan dengan produk dari saluran tataniaga 3 ke pedagang pengecer setelah melalui proses pengemasan dan pelabelan organik. Harga jual di tingkat petani sebesar Rp. 14.500. Pedagang pengecer menyalurkan produk buah naga merah organik ke konsumen dengan harga jual Rp. 20.000/ kg. Pada tingkat pedagang pengecer terdapat penyusutan kuantitas buah naga merah organik sebesar $2 \%$ akibat adanya fungsi penyimpanan.Konsumen yang terdapat pada saluran tataniaga 3 sejumlah 25 orang dengan asumsi rata-rata pembelian $2 \mathrm{~kg}$. 


\section{Analisis Saluran tataniaga 5}

Saluran tataniaga 5 berasal dari satu orang petani responden buah naga merah organik Desa Jambewangi dapat dilihat pada Gambar 6.

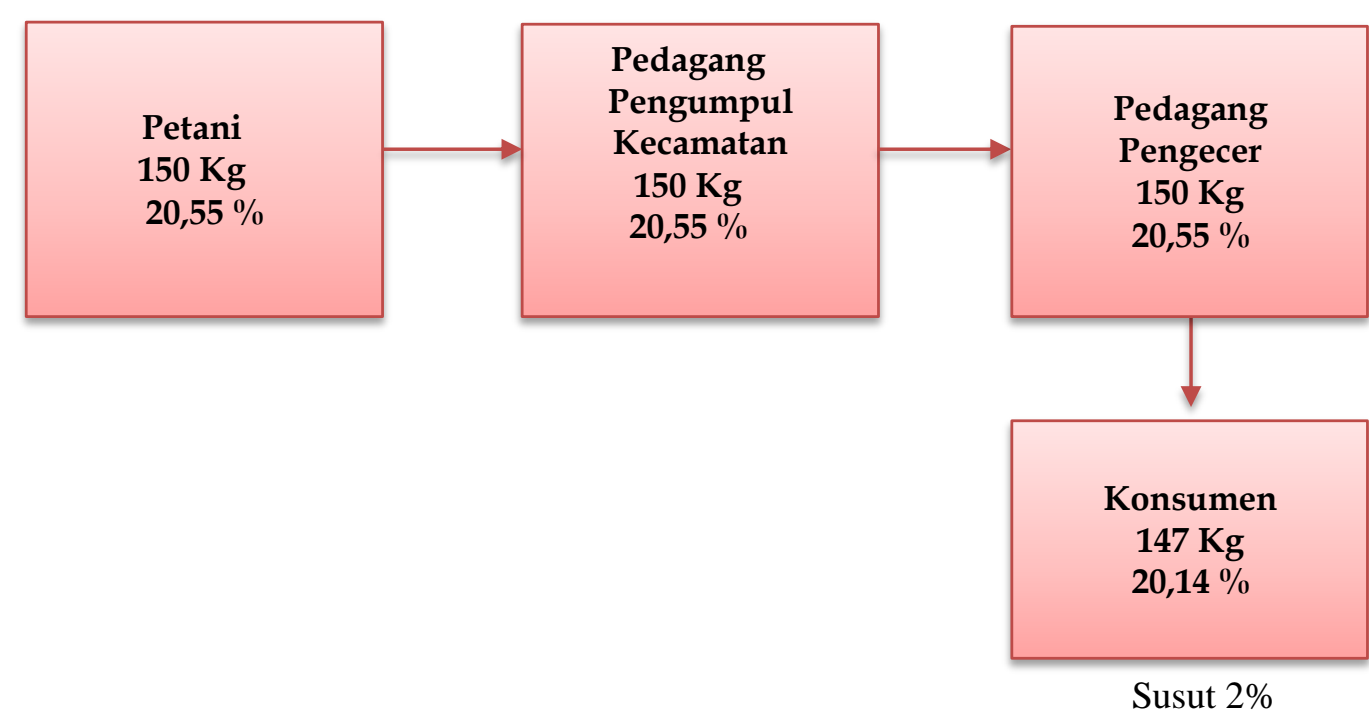

Gambar 6.

Saluran tataniaga 5

Keterangan : $=$ buah naga merah organik sisa sortir

Gambar 6 menunjukkan saluran tataniaga 5, petani responden buah naga merah organik Desa Jambewangi memilih saluran tersebut karena pedagang pengumpul kecamatan bersedia untuk membeli buah naga merah organik sisa sortir secara borongan dari saluran-saluran sebelumnya. Selain itu, petani memilih saluran tataniaga 5 karena keseluruhan biaya tataniaga di luar biaya pemanenan ditanggung oleh pedagang pengumpul kecamatan. Buah naga merah organik yang dijual oleh petani responden pada saluran ini sebesar 150 kg dengan harga jual Rp. 5.000/ kg. Pedagang pengumpul kecamatan kemudian menjual produknya ke pedagang pengecer sebesar $150 \mathrm{~kg}$ dengan harga jual $\mathrm{Rp}$. 6.000. Pedagang pengecer lokal buah naga merah organik selanjutnya menjual ke konsumen dengan harga jual Rp. 8.000/ kg. Pada tingkat pedagang pengecer terdapat penyusutan buah naga merah organik sebesar $2 \%$ dikarenakan adanya fungsi pengangkutan dan fungsi penyimpanan selama sistem tataniaga berlangsung. Konsumen yang terdapat pada saluran tataniaga 5 sejumlah 58 orang dengan asumsi pembelian rata-rata $2,5 \mathrm{~kg}$. 


\section{Analisis Saluran tataniaga 6}

Saluran tataniaga 6 berasal dari satu orang petani responden buah naga merah organik Desa Jambewangi dapat dilihat pada Gambar 7.

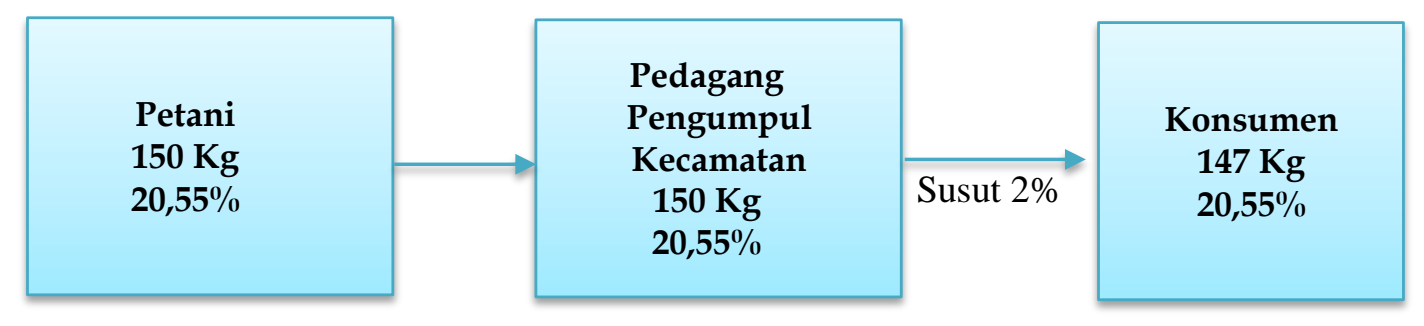

\section{Gambar 7.}

Saluran tataniaga 6

Keterangan: $=$ buah naga merah organik sisa sortir

Gambar 7 menunjukkan saluran tataniaga 6, petani responden buah naga merah organik Desa Jambewangi memilih saluran tersebut karena pedagang pengumpul kecamatan bersedia untuk membeli buah naga merah organik secara borongan (barang sisa sortir) dari saluran-saluran sebelumnya. Selain itu, petani memilih saluran tataniaga 5 karena keseluruhan biaya tataniaga di luar biaya pemanenan ditanggung oleh pedagang pengumpul kecamatan. Buah naga merah organik yang dijual oleh petani responden pada saluran ini sebesar 150 $\mathrm{kg}$ dengan harga jual Rp. 5.000/ kg. Pedagang pengumpul kecamatan kemudian menjual produknya ke pedagang pengecer sebesar $150 \mathrm{~kg}$ dengan harga jual Rp. 7.000. Selain itu, pedagang pengumpul kecamatan juga menjual produk buah naga merah organik secara langsung ke konsumen dengan harga jual Rp. 8.000 kg. Selama sistem tataniaga di tingkat pengumpul kecamatan berlangsung terdapat penyusutan buah naga merah organik sebesar $2 \%$ karena adanya fungsi pengangkutan, bongkar muat dan penyimpanan. Konsumen yang terdapat pada saluran tataniaga 5 sejumlah 58 orang dengan asumsi pembelian rata-rata $2,5 \mathrm{~kg}$.

\section{Analisis Saluran tataniaga 7}

Saluran tataniaga 7 berasal dari satu orang petani responden buah naga merah organik Desa Jambewangi dapat dilihat pada Gambar 8. Gambar 8 menunjukkan saluran tataniaga 7 , petani responden buah naga merah organik menjual langsung pada konsumen apabila konsumen datang kepada petani pada saat pemanenan. Saluran tataniaga 7 merupakan saluran tataniaga terpendek dalam sistem tataniaga buah naga merah organik Desa Jambewangi. Pada saat penelitian terdapat 2 orang konsumen yang datang untuk membeli 
buah naga merah organik sebanyak $15 \mathrm{~kg}$ dan $20 \mathrm{~kg}$. Harga jual di tingkat petani pada saluran 7 sebesar Rp. 10.000.

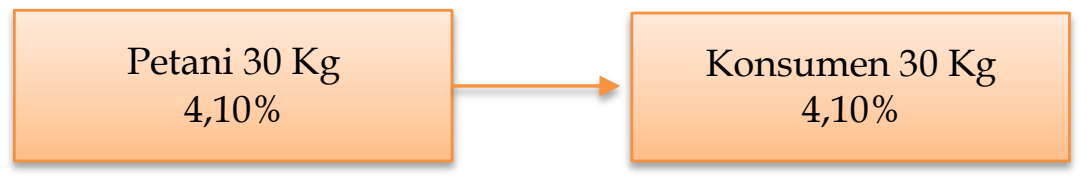

Gambar 8

Saluran tataniaga 7

Keterangan: = buah naga merah organik sisa sortir

Berdasarkan hasil penelitian dapat diketahui bahwa terdapat 7 saluran tataniaga buah naga organik di Desa Jambewangi. Pada 6 saluran tataniaga buah naga organik, pihak pertama yaitu petani akan menyalurkan buah naga organik ke lembaga yang lain seperti pedagang pengumpul desa, pedagang pengecer, pedagang pengumpul kecamatan, dan pedagang pengumpul kabupaten. Hal ini selaras dengan penelitian yang dilakukan oleh (Imang et al., 2019) yang menyatakan bahwa petani melakukan penjualan hasil produksi kepada pedagang pengumpul yang mengambil hasil panen langsung ke lokasi kebun petani. Hal ini sangat membantu petani dalam menjual hasil produksinya dan juga menghemat waktu dan tenaga petani. Setiap petani menjual kepada pedagang pengumpul yang berbeda-beda.

Saluran tataniaga buah naga organik di Desa Jambewangi menunjukkan saluran ke 7 merupakan saluran yang paling efektif dan efisien, dimana petani dapat langsung menjual hasil panennya kepada konsumen. Hal ini dapat meningkatkan keuntungan yang didapatkan oleh petani.

\section{SIMPULAN DAN SARAN}

\section{Simpulan}

Berdasarkan hasil penelitian dan pembahasan dari petani produsen sampai ke konsumen disimpulkan bahwa, saluran tataniaga buah naga merah organik di Desa Jambewangi terdiri dari : a) Petani - Pedagang Pengumpul Desa - Pedagang Pengumpul Kabupaten - Supermarket - Konsumen. b) Petani Pedagang Pengumpul Kabupaten - Supermarket - Konsumen. c) Petani Pedagang Pengumpul Desa - Pedagang Pengecer - Konsumen. d) Petani Pedagang Pengecer - Konsumen. e) Petani - Pedagang Pengumpul Kabupaten Pedagang Pengecer - Konsumen. f) Petani - Pedagang Pengumpul Kabupaten Konsumen. g) Petani - Konsumen. Saluran tataniaga yang paling efisien adalah 
Saluran 7 yaitu pemasaran buah naga organik dari petani kemudian disalurkan secara langsung ke konsumen.

\section{Saran}

Berdasarkan hasil penelitian yang dilakukan, berikut beberapa saran untuk peningkatan sistem tataniaga buah naga merah organik di Desa Jambewangi: Petani disarankan untuk memelihara saluran tataniaga yang telah efisien dan membuat kontrak kerjasama tertulis terkait penanggungan risiko penyusutan produk buah naga merah organik agar tidak hanya merugikan petani dan Lembaga tataniaga disarankan untuk melakukan inovasi pada kemasan sehingga dapat meningkatkan daya simpan dan nilai tambah pada produk.

\section{DAFTAR PUSTAKA}

Ali, M.F., Situmorang, S., Murniati, Ktut. 2017. Analisis Efisiensi Pemasaran Kubis di Kecamatan Gisting Kabupaten Tanggamus. JIIA. 5 (3): 258-266.

Aji, T. N., Subantoro, R., Nurjayanti, E. D. 2015. Analisis Tataniaga Kubis (Brassica oleraceae) (Studi Kasus di Desa Deles Kecamatan Bawang Kabupaten Batang). MEDIAGRO. 11 (1): 24-34.

Amnimarlianda, B. I., Syafii, I., Supriono, A. 2018. Analisis Pemasaran dan Pendapatan Usahatani Semangka Kelompok Tani Ridho Lestari di Desa Tembokrejo Kecamatan Muncar Kabupaten Banyuwangi. JSEP. 11 (2): 46-54.

Anindita, Ratya. 2017. Pemasaran Hasil Pertanian. Penerbit Papyrus : Surabaya Dwiastuti, R. 2017. Metode Penelitian Sosial Ekonomi Pertanian. Malang: UB Press. Herdiansyah, H. 2011. Metodologi Penelitian Kualitatif untuk Ilmu-Ilmu Sosial. Jakarta: Salemba Humanika.

Hidayat, M. I., Suslinawati, Andriani, P. 2016. Analisis tataniaga jeruk siam banjar (Citrullus reticula) di Desa Karang Buah Kecamatan Belawang Kabupaten Barito Kuala. Al Ulum Sains dan Teknologi. 1 (2): 123-131.

Imang, N.Juitai, F.,Honestman,A. 2019. Analisis Usahatani dan Pemasaran Buah Naga (Hylocereus costaricensis) di Desa Sanggulan Kecamatan Sebulu Kabupaten Kutai Kartanegara. Jurnal Agribisnis Komunitas Pertanian 2 (2): 79-86.

Mulyadi, M. 2011. Penelitian kualitatif serta pemikiran dasar menggabungkannya. Jurnal Studi Komunikasi dan Media.15 (1): 127-138.

Side, H. A., Busaeri, S. R., Ilsan, M. 2018. Analisis Sistem Pemasaran Komoditi Bawang Merah dengan Pendekatan SCP di Kelurahan Baruga Dhua, 
Kecamatan Banggae Timur, Kabupaten Majene, Provinsi Sulawesi Barat. WIRATANI. 1 (2): 90-105.

Simatupang, D. I. S. 2016. Analisis Tataniaga Jagung (Studi Kasus: Desa Pergandengan, Kecamatan Tiga Binanga, Kabupaten Karo, Provinsi Sumatera Utara). Majalah Ilmiah Politeknik Bina Mandiri Prestasi. 5 (1): 1014.

Sugiyono. 2017. Metode Penelitian Kuantitatif, Kualitatif, RED. Bandung: Alfabeta. Surahman, T., dan Kusnadi,. 2016. Sistem Pemasaran Nenas Bogor (Ananas comosus) di Kabupaten Bogor. CR Journal. 2 (1): 1-10.

Suryono, Joko. 2006. Mengkonsumsi Buah Naga untuk Obati Berbagai Penyakit. Sinar Tani Edisi 15 - 21 Februari 2006.

Vincy, V. 2016. The Production and Marketing of Banana in Vilavancode Taluk. International Journal of Research-GRANTHAALAYAH. 4 (10): 37-49. 